\section{SPECIFICITY AND EVOLUTION IN DISEASE.}

To the Editor of THE LANCET.

SIR,-I was very much interested in reading the historical retrospect on the above subject by Sir William Job Collins in THE LANCET of May 15th. In my last annual report to the Education Committee, writing in reference to the condition of the children attending the elementary schools, on my return to duty after some four years absence, I said that-

"Owing to various causes, such as stress of the war, the food difficulty shortage of staff, outbreaks of various diseases, the health of the children and teachers has obviously suffered in the health of the children and teachers has obviously suffered in many cases ...... in this connexion I might mention that the children attending the schools on the high ground at the back of St. Leonards and Hastings appeared in better health than those in majority of children had sufficient in bulk, but it was deficient in quality, and certain essentials, such as fats and sugar, which to any quality, and certain essentials, such as fats and sugar, which to my mind are most important constituents for a growing child, were present epidemic of skin troubles, from which so many of the children are suffering, is in some measure due to the alteration in children are suffering, is in some measure due to the alteration in the diet, since it is possible owing to the constituents of the tissues themselves having become modified they are less able to withstand attacks of infective organisms; also certain microbes which are usually harmless have been able to take on pathogenic
properties owing to such modification of the body tissues. The properties owing to such modification of the body tissues. The
same cause might also account for other epidemics which have been so prevalent during the past year or two."

I made the above remarks with a view to emphasising the fact that certain defects among the children were apparently the result of evolution, brought about by abnormal conditions.

In another part of my report I make the statement:-

"Children do not always eat sweets on account of their attractive taste, but to supply a physiological want, more especially owing to the present shortage of sugar.'

Here, again, I believe that sugar and also fats play a most important part, from the point of view of evolution, in the history of a race, not only as regards diet, but as a prophylactic against disease.

In reference to other diseases, viewed in the light of evolution, many intricate pathological conditions might find a rational explanation. Take, for instance, the ætiology of cancer, might not this be due to an attempt at asexual reproduction on the part of nature at a time of stress? Similar phenomena are known to take place in the lower forms of animal life.

I am, Sir, yours faithfully,

O. POLHILL TURNER, D.P.H. Oxon.,

Hastings, May 18th, 1920. School Medical Officer.

\section{THE FEE FOR CONDUCTING AN AUTOPSY.}

\section{To the Editor of THE LANCET.}

SIR, - Would it not be a good thing to make an effort to get the fee paid for making a post-mortem examination by order of a coroner increased? A fee of one guinea was, to say the best of it, small before the war. It is now miserably inadequate. A post-mortem examination cannot be properly made in under an hour. It has to be performed at short notice and often at an inconvenient time. It requires considerable skill to perform and to draw the right conclusions from it. In the country there are none of the facilities of a city mortuary, no skilled assistance, and very often no proper cleansing accommodation. In fact, in the country it is often hard to find anything which can be said to really facilitate the examination. I think very few will suggest that if the present fee were trebled it would be excessive.

I am, Sir, yours faithfully,

Weybridge, May 20th, 1920 .

J. W. RoB.

The BRITISH SCIENCE GUILD.-The annual meeting of the British Science Guild will be held at the Goldsmiths' Hall, Foster-lane, London, on Tuesday, June 8th, at 3 P.M. Lord sydenham, G.C.S.I., F.R.S., in vacating a presidency marked by two successful scientific Products Exhibitions, will deliver an address on "Science and the Nation," and this will be followed by an address on "Some National Aspects of Transport" by the incoming President, Lord Montagu of Beaulieu, whose contributions to mobility of many types in India and at home seem likely to be succeeded by illustrations of mobility of quite another type in the urgent and important application of knowledge to national affairs. Applications for invitations to the meeting should be addressed to the Secretary of the British Science Guild, 6, John-street, Adelphi, London, W.C.2.

\section{attedical defters.}

Royal Colleges of Physicians of London and SURGEONS OF ENGLAND.-Examinations for the Diplomas in Psychological Medicine and Ophthalmic Medicine and Surgery of the Royal Colleges of Physicians and Surgeons will commence on June 28th and July 26th respectively. Full information can be obtained from the Secretary, Examination Hall, 8, Queen-square, Bloomsbury, W.C.1. -

Royal College of SuRgeons of EngLand.At the speciell and ordinary First Professional Examination for the diploma of Fellow, held from May 4th to 15th, 168 candidates presented themselves, of whom 74 were approved and 94 were rejected. The following are the names and medical schools of the successful candidates:-

A. L. A bel, Univ. Coll. ; H. H. Bailey, London Hosp.; J. A. Berry, Guy's; O. Brenner, Birmingham Univ.; R. St. L. Brockman St. Bart. 's; D. J. Browne, Sydney Univ. and Middlesex; A.G. Edinburgh Univ. E. A Coldrey St Bart.'s: S. H. Cookson, Edinburgh Univ.; E. A. Coldrey, St. Bart.'s; S. H. Cookson, Birmingham; H. Corsi, St. Bart.'s and St. Mary's ; R. K. Dadachanji, London H. Corsi, St. Bart.'s and st. Mary's ; R. K. Dadachanji, London T. F. M. Dilworth, St. Thomas's; C. F. T. East, Oxford Univ and King's Coll. ; J. A. W. Ebden, Westminster; D. J. Evans, Birmingham Univ.; G. I. Evans, St. George's; W. C. Faull, St. Mary's; A. W. Fawcett, Bristol Univ.; L. R. Fifield, London W. D. Galloway, Guy's; A. T. Gibb, Manchester Univ.; J. W. Gilbert, Bristol Univ.; P. K. Gilroy, Cambridge Univ, and St. George's; V. B. Gokhale, Bombay and Middlesex; E. Grey, Manchester Univ, and Middlesex; A. R. Gunn, Edinburgh Univ. and St. Bart.'s; S. G. Harrison, St. Bart.'s; F. H. Healey, Birmingham Univ.; S. L. Higgs, Cambridge Univ. and St. Bart.'s ; J. P. Hosford and R. W. P. Hosford, St. Bart's and Univ. Coll ; I. B. Jose, London; N. J, Judah, Edinburgh Univ.: G. L Keynes, Cambridge Univ Juah, St Bart's J. Le M. Kneebone, London; $\mathrm{E}$. A. Linell, Manchester. J. Le M. Kneebone, London ; E. A. Linell, Manchester Univ.;
S. D. Lodge, Leeds Univ.; J. Love, Middlesex; W. M. H. McCullagh, Queen's Univ. and Middlesex; A. C. Maconie. St. Bart.'s; N. S. Macpherson, St. Thomas's; W. C. B. Meyer,

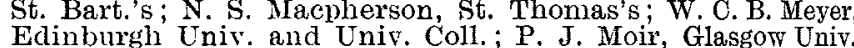
and London; O. G. Morgan, Guy's; D. F. A. Neilson, St. and London; O. G. Morgan, Guy's; D. F. A. Neilson, St. Thomas's; R. L. Newell, Manchester Univ; ; H. G. Oliver, London; L. F. O'Shaughnessy, Durham Univ.; S. T. Parker, Otago Univ. and Middlesex; Eleanor Joyce Partridge, Lond. Sch. Med. for Women; D. H. Patey, Middlesex; C. V. Patrick,
St. Thomas's; P. P. Pughe, Univ. Coll.; F. H. Scotson, Manchester Univ,; S. C. Shanks, Glasgow Univ.; E. S. S. Smalpage Sydney Univ.; J. F. H. Stallman, Guy's; C. Sturton, Cambridge Univ.; C. H.' Terry, St. Bart.'s; C. P. Thomas, Cardiff and Westminster; J. W. T. Thomas, Middlesex; A. H. C. Visick St. Bart.'s; ;E. Watson-Williams, Cambridge and Bristol Unirs. and Mriddlesex; H. P. W. White, Edinburgh Univ. H. A. B. Whitelocke, Middlesex; $O$. H. Williams, Edinburgh and Liverpool Lniv's.; A. D. Wrisht, St. Mary's; and H. B. Yates, St. George's.

Royal College of Physicians of Edinburgh.quarterly meeting of the Roval College of Physicians was held on May 4th, Sir Robert Philip (President) in the chair. Dr. Andrew Graham Ritchie was elected a Fellow of the College. Dr. George Sandison Brock, M.B.E., Dr. Chung Yik Wang, and Dr. Thomas Frederick Corkill were elected Members of the College. The Lister Fellowship for Original Research was awarded to Dr. G. W. Marshall Findlay.

Partin Prize.-This prize of $£ 100$ is open to competitors of all nations. The subject of the essay for the present period is "On the Curative Effects of Carbonic Acid Gas or Other Forms of Carbon in Cholera, for Different Forms of Fever and Other Diseases." Essays intended for competition, which must be written in the English language, to be received by the secretary not later than Dec. 31st, 1920 .

Royal College of Surgeons of Edinburgh:At a meeting of the College held on May 19th the following candidates, having passed the requisite examinations, were admitted Fellows:-

John Stanley Arkle, Cyril Victor Baigent, Harry Banks, Max Richard Boe, Augnst Lyle Buchanan, Charles Henry Corbett, Pares Chandra Datta, John Newbury Fraser Ferguson, Fran Crril Greig, Edward Wilson Hall, Arthur Dodsworth Haydon, Ashler Exnest Herman, William Henry Johnston, Gideon Johannes Joubert, Charles Hardiman Laver Arthur Poole Lawrence, Crichton Raoul Merrillees Rould Merson, Ryder Percival Nash, John Millie Pringle Hubert, Robbins, Parcival Nash, John Milie Pringle, Franl Hubert Robbins, Harold Farley Seymour, Frederick Montgomery Arnold Verse, Rankin Greis Walker, Andrew Walbrugh Arnold Verse, Rankin Greig Walker, Andrew Walbrugh Norval Jaune

The following candidates, having passed the requisite examinations, had the Higher Dental Diploma conferred upon them :-

Donglas Llewellyn George Radford, Charles Henry Kemball, and James Dalgleish Hamilton Jamieson.

At the same meeting the Bathgate memorial prize, con sisting of bronze medal and set of books, was, after a com 